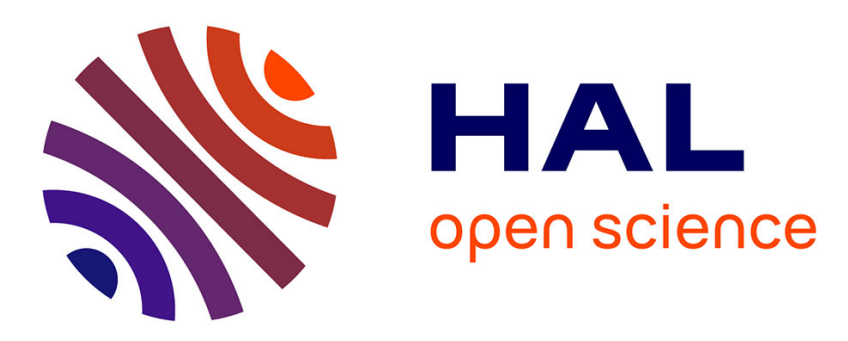

\title{
Virological diagnosis and management of two cases of congenital measles
}

\author{
Delphine Giusti, Julie Burette, Yohan Nguyen, Nicolas Lévêque, Olivier \\ Graesslin, Laurent Andreoletti
}

\section{- To cite this version:}

Delphine Giusti, Julie Burette, Yohan Nguyen, Nicolas Lévêque, Olivier Graesslin, et al.. Virological diagnosis and management of two cases of congenital measles. Journal of Medical Virology, 2013, 85, pp.2136 - 2138. 10.1002/jmv.23702 . hal-03267110

\section{HAL Id: hal-03267110 https://hal.science/hal-03267110}

Submitted on 22 Jun 2021

HAL is a multi-disciplinary open access archive for the deposit and dissemination of scientific research documents, whether they are published or not. The documents may come from teaching and research institutions in France or abroad, or from public or private research centers.
L'archive ouverte pluridisciplinaire HAL, est destinée au dépôt et à la diffusion de documents scientifiques de niveau recherche, publiés ou non, émanant des établissements d'enseignement et de recherche français ou étrangers, des laboratoires publics ou privés. 


\title{
Virological Diagnosis and Management of Two Cases of Congenital Measles
}

\author{
Delphine Giusti, ${ }^{1}$ Julie Burette, ${ }^{2}$ Yohan Nguyen, ${ }^{1}$ Nicolas Lévêque, ${ }^{1}$ Olivier Graesslin, ${ }^{2}$ \\ and Laurent Andreoletti ${ }^{1 *}$ \\ ${ }^{1}$ Medical and Molecular Virology Unit, Faculty of Medicine, Reims, France \\ ${ }^{2}$ Obstetrics and Gynecology Ward, Institute Alix de Champagne, Reims, France
}

Measles is a highly contagious viral infection causing congenital infections with a risk of neurological complications in the newborn. Two cases of measles, which occurred in pregnant women within 14 days before the delivery, are described. Mother-to-child transmission of the virus was documented in the newborns either by RT-PCR in saliva or by $\lg \mathrm{M}$ detection in blood. The measles strains evidenced in saliva samples were genotyped and belonged to the D4 Genotype. An early viral RT-PCR detection allowed successful immunoglobulin prophylaxis in one newborn taking into account that the duration between the onset of the skin rash in the mother and the delivery was less than 6 days. Twenty-four months later, none of the newborns developed classical or neurological clinical signs of measles infection. Measles RT-PCR assay in salivary samples can be used before symptoms develop in the infant to confirm early motherto-child transmission, therefore permitting the use of an immunoglobulin prophylaxis in the newborn. J. Med. Virol.

(C) 2013 Wiley Periodicals, Inc.

KEY WORDS: Infectious disease; pregnancy; mother-to-child transmission; virological diagnosis; immunoglobulin prophylaxis

\section{INTRODUCTION}

Measles is one of the most contagious viral infection of humans and often occurs in explosive epidemics [Moss and Griffin, 2012]. Measles is caused by the RNA measles virus family Paramyxoviridae genus Morbillivirus responsible for community-acquired and nosocomial infections mainly transmitted by respiratory droplets and indirectly by contaminated objects. This strictly human virus is maintained in the population by an unbroken chain of acute infections and could be eradicated by high vaccination rates in the general population [Moss and Griffin, 2012]. Because of insufficient vaccine coverage, this virus is still endemic in developed countries with recurrent epidemic outbreaks.

Measles infection generally resolves favorably however severe complications are possible, especially among infants less than 1-year of age and pregnant women. There is no published data on the risk of inutero transmission to the fetus but measles during pregnancy was associated with high risk of preterm delivery (31\%) [Eberhart-Phillips et al., 1993], and complications in pregnant women such as pneumonia and fever [Ali and Albar, 1997]. The effects on the fetus depend on the stage of pregnancy: abortion, inutero death or prematurity without congenital malformations [Chiba et al., 2003]. When measles break out in pregnant woman few days before or after delivery, there is a risk of congenital measles related to an incomplete transfer of protective antibodies. The clinical picture is highly variable in the newborn: asymptomatic form, skin rash, pneumonia [Gershon, 2001]; the newborn will also have a higher risk of developing early sub-acute sclerosis pan-encephalitis with fulminant course [Campbell et al., 2007; Gutierrez et al., 2010]. In pregnant women the clinical diagnosis is confirmed by virological tests based on classical serological test in the peripheral blood and by RT-PCR of salivary samples allowing early detection of measles virus. In the newborn, the "gold standard" procedure is RT-PCR of salivary samples whereas the serological assay is less significant

The authors report no conflicts of interest.

${ }^{*}$ Correspondence to: Laurent Andreoletti Laboratoire de Virologie médicale et moléculaire, et EA-4684, Hôpital Robert Debré, Avenue du Général Koenig, 51092 REIMS Cedex, France.

E-mail: landreoletti@chu-reims.fr

Accepted 17 June 2013

DOI 10.1002/jmv.23702

Published online in Wiley Online Library

(wileyonlinelibrary.com). 
because of his immune system immaturity. The management of measles during pregnancy is only symptomatic but includes fetal monitoring adapted to the stage of pregnancy. Hospital admission of the pregnant mother is only indicated in the case of severe clinical symptoms, with isolation to avoid nosocomial transmission, which could be dangerous in obstetric care units.

The present report describes the virological diagnosis in two cases of congenital measles. Diagnosis strategy and therapeutic management of newborns are discussed by using intravenous polyvalent immunoglobulin.

\section{CASE REPORT}

The first reported case concerns a 29-year-old woman, primigravida, with a premature rupture of membrane at 31 weeks and 3 days of gestation. On examination there was an erythematous and maculopapular rash confluent on the face with small elements on the neckline associated with a moderate pruritus. Typical catarrhal symptoms that began about 3 days previously were observed. She was admitted in the obstetric department with airway isolation measures. The first day of admission, serology was positive for IgM and negative for IgG by antimeasles ELISA detection assays (Enzygnost, Siemens Healthcare, Marburg, Germany) and measles genomic RNA in salivary sample was detected. Viral Genotyping assay by nested RT-PCR followed by partial sequencing of the N-gene (GenomeLab DTCH Quick Start, Beckman Coulter, Brea, CA) demonstrated that the strain belonged to genotype D4 (not shown). Ten days later, measles IgG antibodies at $500 \mathrm{mUI} / \mathrm{L}$ were detected. She received two doses of IM betamethasone injection (12 $\mathrm{mg})$ and 7 days of amoxicillin (3 g per day) during hospital stage. Seven days after admission, she was discharged from hospital. At 33 weeks and 4 days of gestation labor began and delivery occurred. The newborn weighed $1,950 \mathrm{~g}$ at birth with an Apgar score of 9 at $1 \mathrm{~min}$ and 10 at $5 \mathrm{~min}$. No clinical signs of measles infection were observed. The newborn did not receive immunoglobulin because the mother's rash started over 10 days before [Endo et al., 2001; Sheppeard et al., 2009]. The second day after delivery, ELISA confirmed the presence of anti-measles IgM in newborn peripheral plasma blood samples supporting the diagnosis of congenital measles but unfortunately no saliva sample was available. Two years later, the evolution and the clinical outcome were good for this infant without any detectable neurological complications.

The second case concerns a 20-year-old pregnant woman, third gravida and second para who consulted about catarrhal symptom at 34 weeks and 6 days of gestation. A maculo-papular rash was observed predominating on the chest that appeared only few hours earlier. Koplick's spots were found. Serum obtained on the day of consultation was positive by
ELISA for anti-measles IgM and negative for IgG, confirming the clinical diagnosis. In order to avoid nosocomial transmission risks, she came back home with antipyretic drugs (paracetamol: $3 \mathrm{~g}$ per day). Two days later, she was admitted for delivery. She gave birth to a $2,180 \mathrm{~g}$ girl with an Apgar score of 8 at $1 \mathrm{~min}$ and 10 at $5 \mathrm{~min}$. The newborn did not evidence any clinical signs of measles. Immediately, polyvalent immunoglobulin (Tegeline) was injected by IV route to the newborn $(500 \mathrm{mg} / \mathrm{kg} /$ day $)$ during $48 \mathrm{hr}$. Measles RT-PCR was positive $48 \mathrm{hr}$ after delivery in his salivary sample (Measles virus genotype D4) demonstrating mother-to-child measles transmission and the usefulness of post-exposure immunoglobulin prophylaxis. Because of this prophylactic treatment, no serology was performed. Interestingly the newborn did not develop any clinical signs of measles during hospital stage and 2 years later the clinical outcome was favorable without any neurological complications (Table I).

\section{DISCUSSION}

The measles vaccine coverage is insufficient among young adults in France (87-90\%) and could explain the emergence of local outbreaks [Centers for Disease Control and Prevention (CDC), 2011]. During epidemics, non-immunized pregnant women are at risk subjects and mother-to-child measles transmission inutero can occur. The two-presented cases were hospitalized at the Reims University Hospital Centre during the epidemical outbreak of 2011 during which around 14,000 cases were declared with a patient median age of 15 years and a high proportion of young adults among hospitalized cases (46\%) [Centers for Disease Control and Prevention (CDC), 2011]. In the first case, the newborn was born prematurely 14 days after the rash of his mother. This newborn did not receive polyvalent immunoglobulin because it was considered that maternal specific antibodies protected him 10 days after the mother's cutaneous eruption. Finally, this newborn did not develop any clinical signs of measles at birth or neurological complications to date. In the second case, the time between mother's skin rash and birth was only 3 days, therefore supporting an indication of prophylactic immunoglobulin administration to prevent complications in the newborn [Endo et al., 2001]. This second newborn did not develop any clinical signs of measles at birth or later neurological complications. However, this infant should be vaccinated against measles during infancy. In the second case normal human immunoglobulin were used to prevent congenital measles in the newborn; however, immunoglobulin injection was never used in the pregnant women because of potential immunological side effects. The only indication for a pregnant woman is post-exposure prophylaxis within 6 days following a contact with a confirmed measles case [Endo et al., 2001; Sheppeard 
TABLE I. Demographic Clinical and Virological Characteristics of the Two Women and Infants Hospitalized for Congenital Measles

\begin{tabular}{lll}
\hline & & Congenital measles \\
\cline { 2 - 3 } & \multicolumn{1}{c}{ First case } & Second case \\
\hline Clinical and virological findings in the women & & 20 \\
Age (years) & 29 & 3 days \\
Time between rash and delivery & 14 days & Fever, premature delivery \\
Clinical complication & Fever, premature delivery & IgM positive, IgG negative \\
Anti-measles serology & IgM positive, IgG negative & Not done \\
Measles salivary RT-PCR/genotyping assay (N-gene) & Positive/Genotype D4 & $35+1$ day \\
Clinical and virological findings in the newborns & & Not done \\
Age of delivery (G.A weeks) & $33+4$ days & Positive/genotype D4 \\
Serology & IgM positive & 500 mg/kg/day during 2 days \\
Measles salivary RT-PCR/genotyping assay (N-gene) & Not done & Good \\
Polyvalent immunoglobulin & None & Good \\
Clinical outcome & & \\
\hline
\end{tabular}

${ }^{\text {a }}$ Performed the day of hospital admission.

${ }^{\mathrm{b}}$ Tegeline.

${ }^{\mathrm{c}}$ No neurological complications 24-month later.

et al., 2009]. Sheppeard et al. [2009] demonstrated in a study with 265 contacts known to have received prophylaxis that the effectiveness of prophylaxis with normal human immunoglobulin was $75.8 \%$ (CI:0-94) when given within 7 days at a dose of $0.2 \mathrm{ml} / \mathrm{kg}$ and $100 \%$ for prophylaxis with measles, mumps and rubella (MMR) vaccine when given within 3 days. A report of 20 contacts given immunoglobulin prophylaxis in Iowa, United States, did not refer to any secondary case of measles when given within 6 days at a dose of $0.25 \mathrm{ml} / \mathrm{kg}$ while one case was described among 175 subjects receiving post-exposure vaccine [Centers for Disease Control and Prevention (CDC, 2004)]. Although there is no published data on the use of immunoglobulin prophylaxis specifically in newborns, its effectiveness is well established within 6 days and the use of MMR vaccine is not recommended until 6 months.

Finally the use of viral RT-PCR assay of salivary samples allowed rapid and reliable diagnosis of measles infection in one newborn before the presence of clinical signs and the delayed positivity of measles IgM therefore allowing the use of intravenous polyvalent immunoglobulin. Also in case of measles RT-PCR detection, genotyping for viral identification was performed by partial sequencing of $\mathrm{N}$-gene indicating that all the detected strains belonged to the D4 genotype: detected in 24 countries, D4 was the predominant genotype during epidemic outbreak in Europe in 2010-2011 [Parent du Châtelet et al., 2010; Centers for Disease Control and Prevention, 2011 ]. As reported recently, more than $99 \%$ of the 2011 French strains were identified as MVs/Montaigu. FRA/43/08 and were phylogenetically related to an initial D4 variant previously identified in the United Kingdom during 2007 (MVs/Enfield.GBR/14/ 07 strain) [Parent du Châtelet et al., 2010]. These findings associated with the present report highlight the need for an efficient European epidemiological and virological survey for local measles outbreaks identification in order to perform an early molecular diagnosis of mother-to-child measles infection and a better clinical and therapeutic management in pediatric wards.

\section{REFERENCES}

Ali ME, Albar HM. 1997. Measles in pregnancy: Maternal morbidity and perinatal outcome. Int J Gynaecol Obstet 59:109-113.

Campbell H, Andrews N, Brown KE, Miller E. 2007. Review of the effect of measles vaccination on the epidemiology of SSPE. Int $\mathrm{J}$ Epidemiol 36:1334-1348.

Centers for Disease Control and Prevention (CDC) 2004. Postexposure prophylaxis, isolation, and quarantine to control an import-associated measles outbreak-Iowa, 2004. MMWR Morb Mortal Wkly Rep 53:969-971.

Centers for Disease Control and Prevention (CDC) 2011. Increased transmission and outbreaks of measles-European Region, 2011. MMWR. Morb Mortal Wkly Rep 60:1605-1610.

Chiba ME, Saito M, Suzuki N, Honda Y, Yaegashi N. 2003. Measles infection in pregnancy. J Infect 47:40-44.

Eberhart-Phillips JE, Frederick PD, Baron RC, Mascola L. 1993. Measles in pregnancy: A descriptive study of 58 cases. Obstet Gynecol 82:797-801.

Endo A, Izumi H, Miyashita M, Taniguchi K, Okubo O, Harada K. 2001. Current efficacy of post-exposure prophylaxis against measles with immunoglobulin. J Pediatr 138:926-928.

Gershon AA. 2001. Chickenpox, measles and mumps. In: Remington JS, Klein JO, editors. Infectious diseases of the fetus and newborn infant 5th edition. Philadelphia: WB Saunders. pp $375-427$.

Gutierrez J, Issacson RS, Koppel BS. 2010. Subacute sclerosing panencephalitis: An update. Develop Med Child Neurol 52: 901-907.

Moss WJ, Griffin DE. 2012. Measles. Lancet 379:153-164.

Parent du Châtelet I, Antona D, Freymuth F, Muscat M, Halftermeyer-Zhou F, Maine C, Floret D, Lévy-Bruhl D. 2010. Spotlight on Measles 2010: Update on the Ongoing Measles Outbreak in France, 2008-2010. Eurosurveillance 15. http:// www.eurosurveillance.org/ViewArticle.aspx?ArticleId=19656

Sheppeard V, Forssman B, Ferson MJ, Moreira C, Campbell-Lloyd S, Dwyer DE, McAnulty JM. 2009. The effectiveness of prophylaxis for measles contacts in NSW. NSW Public Health Bull 20:81-85. 